\title{
Al-Chizan
}

Jurnal Pemikiran Hukum Islam

ISSN 1907-0985, E ISSN 2442-8256

Vol. 13, No. 2, 2017, h. 243-271

DOI: https://doi.org/10.30603/am.v13i2.913

\section{Effectiveness of the Implementation of Supreme Court Regulation Number 3 of 2017 in the Marisa Religious Court}

\author{
Lulu Sarini \\ Kementerian Agama Kabupaten Pohuwato \\ Email: lulusarini@gmail.com
}

Abstract: This study aims to determine the effectiveness of the implementation of Supreme Court Regulation No. 3 of 2017 Concerning Guidelines for Judging Women Against the Law (PERMA). This research is a field research with data collection methods such as observation, interview and documentation study. The collected data is processed and analyzed with qualitative descriptive. The results of the study showed that the Judges at the Marisa Religious Court in deciding divorce divorce cases before and after the issuance of the regulation had not yet enumerated the request for the Petitioner to pay the burden. However, due to the Circular of the Mahkamah Agung Number 1 of 2017, there is a wife's right to pay. In relation to the effectiveness of the PERMA, it has been effective in enforcing gender justice in the Marisa Religious Court. In certain divorce divorce cases, the wife is present and submits a reconciliation claim regarding livelihood at the hearing, and verstek and case matters where his wife does not submit a liability claim then the PERMA is ineffective or not applied.

Keywords: Regulation, Supreme Court, Marisa Religious Court

\section{Efektifitas Pelaksanaan Peraturan Mahkamah Agung Nomor 3 Tahun 2017 di Pengadilan Agama Marisa}

Abstrak: Penelitian ini bertujuan untuk mengetahui efektifitas pelaksanaan Peraturan Mahkamah Agung Nomor 3 Tahun 2017 tentang Pedoman Mengadili Perempuan Berhadapan dengan Hukum. Penelitian ini adalah penelitian lapangan dengan metode pengumpulan data berupa pengamatan, wawancara dan studi dokumentasi. Data yang terkumpul diolah dan dianalisis dengan desktiptif kualitatif. Hasil penelitian menunjukkan bahwa Hakim-hakim di Pengadilan Agama Marisa dalam memutuskan perkara cerai 
Efektifitas Pelaksanaan Peraturan Mahkamah Agung

Nomor 3 Tahun 2017 di Pengadilan Agama Marisa

talak sebelum dan setelah diterbitkannya peraturan tersebut belum ada amar yang menyebutkan kepada Pemohon untuk membayar beban. Namun karena adanya Surat Edaran Mahkamah Agung Nomor 1 Tahun 2017 maka terdapat amar pembayaran hak istri. Terkait efektifitasnya PERMA tersebut sudah efektif menegakkan keadilan gender di Pengadilan Agama Marisa, pada perkara cerai talak tertentu, istri hadir dan mengajukan tuntutan rekonvensi tentang nafkah di persidangan, dan perkara verstek maupun perkara yang istrinya tidak mengajukan tuntutan nafkah maka PERMA tersebut tidak efektif atau tidak diterapkan.

Kata Kunci: Peraturan, Mahkamah Agung, Pengadilan Agama Marisa

\section{A. Pendahuluan}

Pemaknaan sensitifitas gender yang sering dikumandangkan itu, lebih bermaksud menunjuk kalangan perempuan sebagai objeknya. Bagi mereka (yang menggaungkan keadilan gender berlebihan), manakala berhadapan dengan hukum, perempuan senantiasa dirugikan. Hak-hak mereka diabaikan karena dianggap 'makhluk kelas dua'. Sikap terhadap mereka pun cenderung kasar saat berhadapan dengan hukum keluarga, menciderai halusnya psikis kaum hawa. Bagi mereka, pengadilan agama khususnya, telah dinaungi oleh unsur warisan turun temurun yang disebut superioritas laki-laki dan/atau ideologi patriarki yang mereka sebut fikih patriarkis, sebaliknya perempuan berada di titik sobordinatif.

Lahirnya Undang-Undang Nomor 1 Tahun 1974 tentang Perkawinan salah satu tujuannya adalah untuk mengembalikan harkat dan derajat kaum perempuan Indonesia. Hal tersebut dapat dibaca dalam penjelasan UndangUndangPerkawinan tersebut, dimana salah satu prinsip atauazasnya adalah, menempatkan kedudukan yang seimbang antara lelaki (suami) dan perempuan (istri) baik dalam kehidupan rumah tangga maupun dalam pergaulan masyarakat, sehingga segala sesuatu dalam keluarga dapat dirundingkan dan diputuskan bersama oleh suami dan istrinya. ${ }^{1}$

Hal tersebut berbeda dengan kedudukan kaum perempuan (istri) dalam KUHPerdata, dimana seorang istri tidak dapat tampil di depan

${ }^{1}$ Muhammad Amin Summa, Hukum Keluarga Islam di dunia Islam (Jakarta: Raja Grafindo Persada, 2005), 152. 


\section{Lulu Sarini}

pengadilan tanpa bantuan suaminya, meskipun dia kawin tidak dengan harta bersama atau dengan harta terpisah, atau meskipun dia secara mandiri menjalankan pekerjaan bebas. Seorang istri tidak dapat menghibahkan, memindahtangankan, menggadaikan barang miliknya, memperoleh apapun, baik secara cuma-cuma maupun tanpa beban, tanpa bantuan suami dalam suatu akta atau izin tertulis. Sekalipun suami telah memberi kuasa kepada istrinya untuk membuat akta perjanjian tertentu, si istri tidak berwenang untuk menerima pembayaran apapun, atau memberi pembebasan untuk itu, tanpa izin tegas dari suami. ${ }^{2}$

Dengan demikian salah satu azas Undang-Undang Nomor 1 Tahun 1974 tentang Perkawinan adalah "pro-gender" (berpihak kepada kepentingan kaum perempuan) daripada peraturan-peraturan perkawinan dalam KUHP perdata yang terlalu "bias-gender" (berpihak kepada kepentingan kaum lelaki). Namun demikian dalam proses peradilannya yang diatur dalam Peraturan Pemerintah Nomor 9 Tahun 1975 tentang Peraturan Pelaksanaan Undang-Undang Nomor 1 Tahun 1974 tentang Perkawinan, ternyata hukum acara yang mengatur tatacara mengadili masalah-masalah perkawinan masih mengandung "bias-gender". Karena, jika seorang suami akan mengajukan permohonan cerai talak, maka permohonan tersebut harus diajukan di Pengadilan Agama yang mewilayahi tempat tinggalnya, sedang jika seorang istri akan mengajukan gugat cerai kepada suaminya, maka surat gugatan diajukan kepada Pengadilan Agama yang mewilayahi tempat tinggal tergugat (suaminya), kecuali suaminya dalam keadaan ghoib. ${ }^{3}$

Lahirnya Undang-Undang Nomor 7 Tahun 1989 tentang Peradilan Agama sebagaimana telah diubah dengan Undang-Undang Nomor 3 Tahun 2006 dan terakhir diubah dengan Undang-Undang Nomor 50 Tahun 2009, salah satu tujuannya adalah juga untuk melindungi pihak istri (kaum perempuan), di mana dalam hal seorang suami yang akan mengajukan permohonan cerai talak terhadap istrinya, maka permohonan tersebut diajukan di Pengadilan Agama yang mewilayahi tempat tinggal istrinya. ${ }^{4}$ Sebaliknya jika seorang istri mengajukan gugatan perceraian, tidak diajukan

${ }^{2}$ Lili Rasyidi, Hukum Perkawinan dan perceraian di Malaysia dan Indonesia (Cet. X: Bandung: Penerbit Alumni, 1982), 98.

${ }^{3}$ Zahri Hamid, Pokok-Pokok Hukum Perkawinan Islam dan Undang-Undang Perkawinan di Indonesia, (Cet I; Yogyakarta: Bina Cipta, 1987), 68.

${ }^{4}$ Rahmat Hakim, Hukum Perkawinan Islam. (Bandung: CV Pustaka Setia, 2000), 152. 
Efektifitas Pelaksanaan Peraturan Mahkamah Agung

Nomor 3 Tahun 2017 di Pengadilan Agama Marisa

ke Pengadilan yang daerah hukumnya meliputi tempat kediaman suaminya (tergugat), tetapi ke Pengadilan Agama yang daerah hukumnya meliputi tempat kediaman istrinya (penggugat). ${ }^{5}$ Dengan demikian hakekat UndangUndang Peradilan Agama adalah pro-gender sepanjang dalam pra-prosesnya. Namun dalam implementasi persidangannya tentu wajib dipedomani azasazas hukum dan peradilan serta hukum acara yang berlaku dalam rangka menegakkan hukum dan keadilan dalam masyarakat.

Syari'at Islam telah mengajarkan bahwa Allah swt. memberikan penghargaan dan balasan atas amal perbuatan kaum lelaki dan kaum perempuan adalah sama. ${ }^{6}$ Bahwa proses akad pernikahan harus dilakukan dengan baik yang didahului dengan peminangan (khitbah), syarat dan rukun akad nikah juga wajib terpenuhi, bahkan di Indonesia akad nikah dilaksanakan dengan segala proses adat dan budaya yang tidak bertentangan dengan syariat Islam, dan setelah akad nikah selesai, suami berkewajiban mempergaulinya dengan baik. Demikian pula ketika suami berkeinginan kuat untuk mengakhiri perkawinan dengan menjatuhkan talak kepada istrinya, sekalipun istrinya tersebut belum pernah disentuhnya (digaulinya), maka Allah swt mewajibkan kaum lelaki para suami untuk memberikan mut'ah yang patut, karena perceraian harus dilakukan dengan baik. ${ }^{7}$

Oleh karena itu syariat Islam mewajibkan pemberian mut'ah bagi para suami yang menceraikan istrinya sekalipun istrinya tersebut belum disentuhnya (digaulinya), maka berdasarkan teori a contrario (mafhum mukhalafah)-nya perceraian dengan masa perkawinan yang cukup lama dimana pihak perempuan telah mengorbankan keperawanannya dan melayani suaminya untuk beberapa waktu bahkan telah berhasil mengandung dan melahirkan anak karena digauli oleh suaminya tersebut, maka amat bijaksana apabila hakim juga menetapkan mut'ah yang menjadi hak perempuan tersebut. Karena diantara tujuan pemberian mut'ah adalah untuk menghibur hati serta mengurangi rasa kesedihan sebagai akibat perceraian yang terjadi karena keinginan suaminya. ${ }^{8}$ Sehingga sangat arif dan bijaksana atau dapat

\footnotetext{
${ }^{5}$ Fidaweri, Hukum Islam Tentang Fasakh Perkawinan, (Jakarta: Pedoman Ilmu Jaya, 1989), 98.

${ }^{6}$ Lihat QS al-Hujurat/49: 13, yang mengandung arti "sesungguhnya orang yang paling mulia di hadapan Allah adalah orang-orang yang bertaqwa".

${ }^{7}$ Lihat QS al-Baqarah/): 213, yang mengandung arti "ceraikanlah mereka dengan cara yang baik".

${ }^{8}$ Djamil Latif, Aneka Hukum Perceraian di Indonesia, (Cet. ke-1, Jakarta: Ghalia Indonesia, 1982), 36.
} 


\section{Lulu Sarini}

الطلاق بالرجل العدة : memenuhi keadilan gender apabila para ahli fikih berpendapat للنساء, maksudnya: talak itu hak suami, dan iddah itu hak dari istri, maka sangat bijaksana apabila pelaksanaan hak dan kewajiban tersebut dilaksanakan dalam satu waktu. ${ }^{9}$

Pada tanggal 11 Juli 2017, Mahkamah Agung RI telah menerbitkan Peraturan Mahkamah Agung Nomor 3 Tahun 2017 tentang Pedoman Mengadili Perkara Perempuan Berhadapan Dengan Hukum yang diundangkan pada tanggal 4 Agustus 2017, ${ }^{10}$ Pasal 1 ayat (1), PERMA Nomor 3 Tahun 2017 mendefinisikan, bahwa yang dimaksud "perempuan berhadapan dengan hukum adalah perempuan yang berkonflik dengan hukum, perempuan sebagai korban, perempuan sebagai saksi, atau perempuan sebagai pihak." 11 Dengan demikian PERMA ini juga dapat dijadikan sebagai dasar atau payung hukum oleh hakim dalam mengadili perempuan sebagai pihak dalam perkara perdata di Pengadilan Agama, terutama dalam perkara perceraian yang merupakan $90 \%$ lebih dari perkara perdata agama di Indonesia.

Pasal 1 ayat (4) dan ayat (6) PERMA Nomor 3 Tahun 2017 mendefinisikan, bahwa yang dimaksud kesetaraan gender adalah kesamaan dan keseimbangan kondisi antara laki-laki dan perempuan untuk memperoleh kesempatan dan hak-haknya sebagai manusia. Sedang "keadilan gender adalah suatu proses untuk menjadi adil terhadap laki-laki dan perempuan", ketika keduanya berhadapan dengan hukum. Maka ketika Hakim mengadili perempuan yang berhadapan dengan hukum, yakni menjadi pihak dalam suatu perkara, Hakim wajib memperhatikan azas-azas: a) penghargaan atas harkat dan martabat manusia, b) non diskriminasi, c) Kesetaraan Gender, d) persamaan di depan hukum, e) keadilan, f) kemanfaatan, dan g) kepastian hukum. Hal tersebut bertujuan untuk menjamin hak perempuan terhadap akses yang setara dalam memperoleh keadilan (Pasal 2 dan 3). ${ }^{12}$

\footnotetext{
${ }^{9}$ Mansour Fakih, Analisis Gender dan Transformasi Sosial, (Cet. ke-7. Yogyakarta: Pustaka Pelajar, 2003), 232.

${ }^{10}$ www.badilag.net, "Info sekitar Badilag tertanggal 22-9-2018". Diakses pada tanggal 20 Maret 2019.

${ }^{11}$ Republik Indonesia, Peraturan Mahkamah Agung Nomor 3 Tahun 2017 tentang Perempuan Berhadapan dengan Hukum, pasal 1 ayat (1)

${ }^{12}$ Republik Indonesia, Peraturan Mahkamah Agung Nomor 3 Tahun 2017 tentang Perempuan Berhadapan dengan Hukum, pasal 1 ayat (4) dan (6), pasal 2, pasal 3.
} 
Efektifitas Pelaksanaan Peraturan Mahkamah Agung

Nomor 3 Tahun 2017 di Pengadilan Agama Marisa

Dalam mempertimbangkan keadilan gender Hakim harus menggali nilai-nilai hukum, kearifan lokal dan rasa keadilan yang hidup dalam masyarakat guna menjamin kesetaraan gender (pasal 6 huruf c), tentunya nilai-nilai hukum yang terdapat di dalam Al-Qur'an, As-Sunnah, kitab-kitab Fiqih dan Kompilasi Hukum Islam yang merupakan hukum yang hidup dalam sebagian besar masyarakat Indonesia.

Penerapan PERMA Nomor 3 Tahun 2017 tentang Perempuan Berhadapan dengan Hukum selanjutnya diatur dalam Surat Edaran Mahkamah Agung Nomor 1 Tahun 2017 tentang Pemberlakuan Rumusan Hasil Rapat Pleno Kamar Mahkamah Agung Tahun 2017 dan Surat Edaran Mahkamah Agung Nomor 3 Tahun 2018 tentang pemberlakuan rumusan hasil rapat pleno kamar mahkamah agung tahun 2018. Di sinilah peran para hakim khususnya hakim Pengadilan Agama Marisa merespon upaya-upaya perlindungan hak-hak perempuan melalui responsif gender.

\section{B. Upaya Hakim Pengadilan Agama Marisa dalam Menjamin Eksekusi Nafkah Istri Pada Perkara Perceraian Sebelum Ditetapkannya PERMA Nomor 3 Tahun 2017 Sebagai Upaya Penegakan Keadilan Gender}

Sebelum adanya PERMA Nomor 3 Tahun 2017 tentang Pedoman Mengadili Perempuan Berhadapan dengan Hukum, eksekusi nafkah istri pada perkara cerai talak berpedoman pada Sema 1 tahun 2015, yang intinya melarang pencantuman amar pemberian nafkah istri pada perkara cerai talak sebelum diucapkan ikrar talak karena akan menimbulkan eksekusi prematur.

Majelis Hakim di Pengadilan Agama Marisa dalam rangka upaya menjamin eksekusi nafkah istri dengan pendekatan persuasif yang ditempuh oleh pihak Pengadilan akibat belum dipenuhinya kewajiban nafkah istri, tidak berdasarkan peraturan tertulis apapun, baik perundang-undangan, SK Mahkamah Agung, SK Pengadilan Tinggi Agama, maupun SK Pengadilan Agama. Sebagaimana yang dikatakan oleh Bapak Himawan Tatura Wijaya, S.H.I., selaku Wakil Ketua Pengadilan Agama Marisa, ${ }^{13}$ hal ini dilakukan semata-mata hasil ijtihad hakim dalam upaya menegakkan hukum dan menjamin pelaksanaan Peradilan yang seadil-adilnya, serta demi melindungi hak istri sebagai pihak yang lemah ketika terjadi perceraian.

\footnotetext{
${ }^{13}$ Himawan Tatura Wijaya, S.H.I., Wakil Ketua Pengadilan Agama Marisa, Wawancara pada tanggal 16 April 2019.
} 


\section{Lulu Sarini}

Langkah tersebut telah dilakukan sejak dahulu dan dipertahankan pelaksanaanya sampai saat ini.Sebab sangat efektif dan efisien untuk menjamin terlaksananya eksekusi nafkahistri. Keefektifan upaya pendekatan persuasif tersebut dapat dilihat dengan tidak adanya pengajuan permohonan eksekusi oleh pihak kedua. Dan biasanya pihak kedua sudah dapat menerima dengan lapang dada, upaya yang dilakukan oleh Pengadilan Agama Marisa ini sudah menjadi anjuran dan kebijakan umum yang harus ditempuh.

Ketika sebuah perkara permohonan cerai talak dikabulkan dan putusannya telah mempunyai kekuatan hukum tetap, maka Pengadilan Agama dapat mengadakan sidang penyaksian ikrar talak, sejak itulah perceraian terjadi dan ikatan perkawinan antara suami istri menjadi putus. Pada waktu sidang ikrar talak, apabila suami masih belum mampu melunasi seluruh kewajibannya, maka hakim meminta pendapat istri. Jika istri tidak keberatan ikrar talak diucapkan walaupun haknya belum diterima, maka ikrar dilaksanakan. Sedangkan jika istri keberatan, maka sidang ditunda untuk memberi jeda waktu (kesempatan) suami memenuhikewajibannya.

Lama penundaan persidangan sesuai dengan kesediaan suami dengan syarat tidak melebihi tempo enam bulan. Jika tenggang waktu enam bulan hampir habis dan suami belum melaporkan diri kepaniteraan, maka pihak Pengadilan mengirimkan surat panggilan sidang kepada kedua pihak dengan jadwal yang ditentukan Pengadilan. Dari sini timbullah kekhawatiran akankah suami dengan i'tikad baik membayar semua nafkah yang telah ditentukan oleh Pengadilan. Sebab dengan berakhirnya proses persidangan, maka suami terlepas dari istri, sehingga tidak ada lagi pihak-pihak yang dapat menjamin hak istri. Dengan adanya kekhawatiran semacam itulah maka pihak Pengadilan membuat upaya lain untuk menjamin terlaksananya eksekusi nafkah istri pada perkara cerai talak.

Sebagaimana yang dikatakan oleh Arlin Abdullah Albakir, S.H., selaku Panitera, bahwa Pengadilan Agama dalam hal ini majelis hakim yang memeriksa permohonan cerai talak tidak melakukan upaya khusus untuk menjamin eksekusi nafkah tersebut. Mereka hanya memberi informasi kepada pihak istri bahwa, apabila suami tidak melaksanakan isi keputusan secara sukarela, maka istri dapat mengajukan permohonan eksekusi guna melindungi haknya. Namun dalam prakteknya, tidak pernah ada kasus pengajuan permohonan eksekusi terhadap rekonvensi nafkah istri dalam perkara cerai talak. Hal ini dikarenakan ada beberapa alasan, sebagai berikut: 
Efektifitas Pelaksanaan Peraturan Mahkamah Agung

Nomor 3 Tahun 2017 di Pengadilan Agama Marisa

\section{Biaya Eksekusi yang Dibebankan Kepada Istri}

Menurut pasal 89 ayat (1) UU Nomor 7 Tahun 1989 dijelaskan, bahwa biaya perkara dalam bidang perkawinan dibebankan kepada istri.Hal ini mengakibatkan istri enggan untuk mengajukan permohonannya, mereka lebih memilih bersikap pasrah.

2. Besarnya Biaya Eksekusi yang Tidak Sebanding dengan Jumlah Nafkah

Biaya eksekusi tidaklah murah sebab melibatkan banyak pihak, sehingga yang harus dikeluarkan bermacam-macam. Kadangkala eksekusi harus dilakukan berkali-kali, karena hambatan-hambatan yang terjadi dilapangan. Seperti pihak termohon yang tidak bekerjasama, sulitnya medan, ada pihak ketiga yang turut campur, dan lainsebagainya, Jumlah nafkah yang dibebankan kepada suami biasanya tidak begitu besar karena para pihak yang berperkara umumnya dari masyarakat taraf ekonomi menengah. Bila terjadi permohonan eksekusi, maka biaya yang harus dikeluarkan tidak sebanding dengan harta yang akandiperoleh.

\section{Tidak Ada Harta yang Dieksekusi}

Kadangkala keengganan suami untuk melunasi kewajiban nafkah istri disebabkan keadaan ekonomi suami yangterbatas.

4. Tidak Ada Ketentuan Prodeo

Dalam permohonan eksekusi tidak dikenal istilah prodeo, sehingga semua beban biaya yang dikeluarkan seratus persen harus ditanggung para pihak (pemohon). ${ }^{14}$

Langkah-langkah yang dilakukan oleh Pengadilan Agama Marisa dengan mengadakan pendekatan persuasif akibat belum dipenuhinya kewajiban nafkah istri, tidak didasarkan pada peraturan perundangundangan apapun. ${ }^{15}$ Semata-mata hasil ijtihad hakim dalam upaya menegakkan hukum dan menjamin pelaksanaan peradilan yang seadiladilnya. Hal ini tidak bertentangan dengan perundang-undangan di Indonesia yang menganut aliran rechtvinding, yang berarti bahwa hakim dalam memutuskan sesuatu disamping berpegangan pada undang-undang juga pada hukum lain yang berlaku dimasyarakat. Aliran ini berpandangan bahwa:

\footnotetext{
${ }^{14}$ Arlin Abdullah Albakir, S.H., Panitera Pengadilan Agama Marisa, Wawancara, di Pengadilan Agama Marisa, tanggal 16 April 2019.

${ }^{15}$ Himawan Tatura Wijaya, S.H.I., Wakil Ketua Pengadilan Agama Marisa, Wawancara, di Pengadila Agama Marisa, tanggal 16 April 2019.
} 


\section{Lulu Sarini}

a. Undang-undang tidak dapat menyelesaikan tiap permasalahan yang timbul, sebab undang-undang tidak dapat terperinci (mendetail) melainkan hanya memberikan algemeene rehhtlijnen (pedoman umum) saja.

b. Undang-undang tidak dapat sempurna.

c. Undang-undang tidak dapat lengkap dan tidak dapat mencakup segalagalanya, di sana-sini selalu ada leemten (kekosongan dalam undangundang). ${ }^{16}$

Pasal 14 ayat (1) Undang-Undang Nomor 14 Tahun 1970 menegaskan bahwa Pengadilan tidak boleh menolak, memeriksadan menggali suatu perkara yang diajukan dengan dalih bahwa hukum tidak atau kurang jelas. Ketentuan ini membuktikan bahwa tugas hakim di samping sebagai penegak hukum dan keadilan, tidak saja mengadili berdasarkan hukum-hukum yang ada tetapi harus menciptakandan menemukan hukum berdasarkan pandangan dan nilai-nilai hukum yang hidup dalam masyarakat.

Atas dasar tersebut kiranya apa yang dilakukan oleh hakim Pengadilan Agama Marisa dalam melakukan suatu upaya untuk menjamin terlaksananya eksekusi nafkah istri dalam perkara cerai talak sudah tepat dan benar, sebab memang tidak ada aturan baku tentang hal tersebut. Di samping itu pula apa yang dilakukan pihak Pengadilan Agama Marisa tidak menyalahi aturan tertulis yang telah ditetapkan dan berlaku diIndonesia.

Seorang hakim dalam ajaran hukum Islam diposisikan sebagai seorang mujtahid, yang harus mengambil kesimpulan hukum dari hukum yang wajib diterapkan ketika tidak ada nash. Namun perlu diperhatikan ijtihad diharamkan pada:

a. Perkara yang telah ada hukumnya dan ditetapkan berdasarkan dalil yang sharih dan qath'i.

b. Bila orang yang melakukan ijtihad belum mencapai tingkatan faqih.

Jadi haramnya hukum ijtihad dalam hal ini adalah, pertama karena ijtihad tidak boleh dilakukan pada hal-hal yang telah ada aturan hukumnya, kedua karena orang yang berijtihad tidak (belum) memenuhi syarat-syarat yang dituntut untuk ijtihad.

\footnotetext{
${ }^{16}$ Himawan Tatura Wijaya, S.H.I., Wakil Ketua Pengadilan Agama Marisa, Wawancara, di Pengadila Agama Marisa, tanggal 16 April 2019.
} 
Efektifitas Pelaksanaan Peraturan Mahkamah Agung

Nomor 3 Tahun 2017 di Pengadilan Agama Marisa

Dengan demikian ijtihad yang dilakukan oleh Hakim Pengadilan Agama Marisa telah sesuai, keputusan upaya yang dipilih adalah hasil setelah mempertimbangkan berbagai hal, disamping itu pula apa yang dilakukan tidak menyalahi aturan tertulis yang telah ada dan berlaku.

Sebagaimana telah disebutkan pada bab sebelumnya, bahwa Islam mewajibkan suami untuk memberi nafkah atau membelanjai istrinya. Sebab dengan adanya ikatan perkawinan, maka istri terikat pada suaminya. Kewajiban ini tidak akan gugur selama sebab dan syarat-syarat istri yang berhak menerima nafkah telah terpenuhi. Jika kemudian suami tidak maumemenuhi kewajibannya, maka menurut madzhab Syafi'i nafkah tersebut menjadi hutang suami yang harus dipertanggung jawabkan. Hutang nafkah tersebut adalah hutang yang sah, tidak akan gugur kecuali kalau telah dilunasi atau dibebaskan.

Atas dasar tersebut jika dalam perkara perceraian seorang istri mengajukan rekonvensi yang salah satunya berisi tuntutan nafkah madhiyah, maka hal tersebut diperbolehkan dan tidak menyalahi aturan agama. Nafkah madhiyah adalah nafkah yang masanya telah lewat tapi masih belum dipenuhi oleh pihak suami. Begitu pula dengan nafkah iddah, seorang suami yang telah mentalak raj'i istrinya, wajib memberi nafkah pada istrinya selama masa iddah, meliputi makanan, pakaian, dan tempat tinggal, dengan pertimbangan seorang istri dapat diruju' kembali selama masa iddahnya belum habis. Masa iddah adalah masa menunggubagi seorang wanita setelah diceraikan suami, di mana dalam masa itu ia tidak boleh menikah lagi dengan orang lain sebelum habis masa iddahnya. Dengan demikian pada dasarnya antara mantan suami dengan mantan istri masih punya hubungan hukum dan masih dalam tanggungannya, oleh karena itu nafkah istri masih jadi tanggung jawab suami.

Merujuk pada kepentingan nafkah bagi istri yang sedang menjalani masa iddahnya, maka tepat kiranya dalam sistem hukum perkawinan di Indonesia, jika suami akan menceraikan istrinya ia harus membayar sejumlah uang sebagai wujud pemberian nafkah, maskan dan kiswah istri. Pemberian ini diwajibkan dengan atau tanpa adanya permintaan dari pihakistri.

Hak ex officio yang diberikan pada hakim Pengadilan Agama, merupakan lex specialis dari asas peradilan perdata yang melarang hakim menjatuhkan putusan atas hal yang tidak dituntut, atau memberikan lebih dari yang diminta, sebagaimana yang diatur dalam pasal 178 ayat (3) HIR. Ketentuan ini dimaksudkan untuk terwujudnya perceraian yang adil dan 


\section{Lulu Sarini}

ihsan dan agar mantan istri yang akan diceraikan suaminya jangan sampai menderita karena tidak mampu memenuhi kebutuhan hidupnya.

Rekonvensi yang diajukan istri sebagai pihak termohon dalam perkara cerai talak, diperbolehkan dan tidak menyalahi aturan hukum, hal ini didasarkan pada pasal 136 ayat (2) KHI jo pasal 24 ayat (2) PP Nomor 9 Tahun 1975, yang berbunyi:

Selama berlangsungnya gugatan perceraian atas permohonan penggugat atau tergugat, Pengadilan Agama dapat:

a. Menentukan nafkah yang harus ditanggung oleh suami

b. Menentukan hal-hal yang perlu untuk menjamin pemeliharaan dan pendidikan anak

c. Menentukan hal-hal yang perlu untuk menjamin terpeliharanya barang-barang yang menjadi hak bersama. ${ }^{17}$

Tata cara pengajuan reconvensi istri, sesuai dengan aturan pasal 123 (a-b) HIR, karena:

a. Diajukan bersama-sama dengan jawaban atas permohonan dari pihak termohon.

b. Diajukan secara lisan ataupun tulisan, keduanyadiperbolehkan

c. Isi gugatan reconvensi masih dalam lingkup wewenang Peradilan Agama. ${ }^{18}$

Pemeriksaan yang dilakukan hakim Pengadilan Agama Marisa terhadap reconvensi istri pun telah sesuai dengan aturan yang ada. Majelis hakim tidak begitu saja mengabulkan tuntutan istri sebagaimana dalam permohonannya sebelum mendengar keterangan dari pihak suami (termohon) sebagai jawaban atas gugatan istri tersebut.

Dalam menghadapi tuntutan istri, hakim membebani istri dengan mengadakan pembuktian atas kebenaran dan keabsahan gugatannya. Sebab yang menjadi dasar ialah bahwa orang yang dituntut itu bebas dari tanggungan, dan penuntut wajib membuktikan keadaan yang berlawanan dengan dasar ini. Terhadap jumlah nafkah memang tidak ada aturan baik dalam hukum Islam maupun hukum perdata di Indonesia yang memuat

${ }^{17}$ Republik Indonesia, Instruksi Presiden Nomor 1 Tahun 1999 tentang Penyebaran Kompilasi Hukum Islam, pasal 136 ayat (2). Lihat pula Republik Indonesia, Peraturan Pemerintah Nomor 9 Tahun 1975, pasal 24 ayat (2).

${ }^{18}$ Republik Indonesia, Het Herziene Indonesisch Reglement, pasal 123 (a-b). 
Efektifitas Pelaksanaan Peraturan Mahkamah Agung

Nomor 3 Tahun 2017 di Pengadilan Agama Marisa

aturan jumlah nominal besarnya nafkah yang harus diterima istri setiap harinya, oleh karena itu dalam memutuskan jumlah nafkah hakim Pengadilan Agama Marisa berbeda-beda putusan antara perkara beda dengan kasus yang sama. Hal ini sebagaimana yang dikatakan oleh Himawan Tatura Wijaya, S.H.I. selaku Wakil Ketua Pengadilan Agama Marisa.

Besarnya nafkah yang dikabulkan tergantung pada faktor permintaan istri dan pertimbangan suami dalam memenuhinya, yang terpenting nafkah tersebut tidak terlalu sedikit, karena akan menyengsarakan istri namun juga tidak terlalu banyak sehingga menyusahkan suami. Hakim tidak akan membebani para pihak di luar batas kemampuannya. Sebagaimana Allah swt. tidak akan membebani manusia di luar batas kesanggupannya, sebagaimana firman Allah swt. dalam QS alBaqarah/2: 286 yang berbunyi: .... لَّكَلَّهُ اللَّهُ نَفْسًا إِلَّا وُسنْعَهَ Artinya: “Allah tidak akan membebani manusia kecuali sebatas kemampuannya"19

Hukum Islam hanya mengenal konsep ma'ruf dalam penetapan jumlah nafkah yang harus dibayar suami.Agar dapatmenghasilkan putusan tentang besar kecilnya nafkah sesuai dengan konsep ma'ruf dalam hukum Islam maka tepatlah kiranya bagi hakim Peradilan Agama Marisa menggunakan berbagai pertimbangan. Di samping pertimbangan kedua belah pihak, juga mempertimbangkan lokasi tempat tinggal istri selama masa iddahnya nanti, sebab nafkah adalah belanja hidup dan belanja hidup disuatu tempat berbeda dengan ditempat lain sehingga keadaan dan kebiasaan yang berlaku disuatu masyarakat menjadi faktor pertimbangan. Pelaksanaan pembayaran nafkah istri oleh mantan suami, dilakukan setelah ada putusan sebab putusan mempunyai kekuatan eksekutorial, yaitu kekuatan untuk dapat dijalankan atau dilaksanakan. Kekuatan tersebut ada berdasarkan kepala putusan yang berbunyi: "DEMI KEADILAN BERDASARKAN KETUHANAN YANG MAHAESA".

Disampaikan Himawan Tatura Wijaya bahwa:

Kewajiban suami terhadap istrinya tidak dilakukan sebelum ada putusan resmi dari Pengadilan. Hal ini tidak berarti pihak Pengadilan melarang suami membayar kewajibannya sebelum ada putusan yang

${ }^{19}$ Himawan Tatura Wijaya, S.H.I., Wakil Ketua Pengadilan Agama Marisa, Wawancara, di Pengadila Agama Marisa, tanggal 16 April 2019. 


\section{Lulu Sarini}

sah namun secara logika seseorang belum mengetahui berapa yang harus dibayar sebelum ada keputusan yang pasti. ${ }^{20}$

Kalau menganalisa suami yang tidak mau membayar kontan nafkahnya, kemudian ia meminta keringanan pihak Pengadilan agar dapat dibayarkan dengan cara dicicil, hal ini diperbolehkan sebab secara hukum tidak ada aturan yang mengharuskan adanya pembayaran tunai.

Pertimbangan lain karena nafkah biasanya dibayar secara berkala untuk tempo waktu tertentu, misalnya sebulan sekali atau satu minggu sekali sehingga pembayaran nafkah iddah untuk tiga bulan sewajarnya tidak sekaligus dibayar. Petugas keuangan atau kasir di Pengadilan Agama Marisa mendapat tugas tambahan selain yang diatur dalam pola Pembinaan dan Pengendalian Administrasi Pengadilan Agama (Bindalmin), yaitu menerima pembayaran nafkah oleh suami yang kemudian diberikan lagi kepada pihak istri setelah ia ditalak dalam penyaksian sidang ikrar talak. Tugas seperti ini meskipun tidak diatur dalam Undang-undang tetapi juga tidak menyalahinya, sebab langkah ini dilakukan untuk tujuan yang mulia. Penerapan aturan tersebut dimaksudkan untuk mencegah kebohongan dalam sidang serta cara agar istri mendapatkan nafkah darisuaminya.

Pelaksanaan pemberian nafkah istri di Pengadilan Agama Marisa, jika istri meminta di luar batas kemampuan suami, maka Hakim akan memadukan antara pendapat istri dengan tanggapan suami. Dengan begitu diharapkan ada kesepakatan yang tidak memberatkan kedua belah pihak. Oleh karena itu, hakim dalam memutuskan memerlukan kejelian sebab putusannya diharapkan adil dan menentramkan pihak-pihak yang berperkara.

Penundaan sidang yang dilakukan Majelis Hakim Pengadilan Agama Marisa jika istri keberatan ditalak sebelum menerima haknya, maka hal tersebut tidak melanggar aturan. Sebab sidang ikrar talak sebagai perwujudan eksekusi ikrar talak, boleh dilakukan kapanpun selama tidak lebih dari enam bulan semenjak putusan tidak mempunyai kekuatan hukum tetap. Sebagaimana dalam pasal 70 ayat (6) Undang-Undang Nomor 7 Tahun 1989 yang berbunyi:

Jika suami dalam tenggang waktu enam bulan sejak ditetapkan hari sidang penyaksian ikrar talak, tidak menghadap sendiri atau tidak mengirimkan walinya meskipun telah mendapatkan penggilan secara

\footnotetext{
${ }^{20}$ Himawan Tatura Wijaya, S.H.I., Wakil Ketua Pengadilan Agama Marisa,
} Wawancara, di Pengadila Agama Marisa, tanggal 16 April 2019. 
Efektifitas Pelaksanaan Peraturan Mahkamah Agung

Nomor 3 Tahun 2017 di Pengadilan Agama Marisa

sah dan patut, maka gugurlah kekuatan penetapan tersebut, dan perceraian tidak dapat diajukan lagi berdasarkan alasan yang sama. ${ }^{21}$

Pasal tersebut dapat dipahami bahwa waktu kadaluarsa dari sidang penyaksian ikrar talak adalah enam bulan, sehingga sidang yang ditunda tidak melanggar hukum. Penundaan ini dimaksudkan sebagai usaha pencegahan (preventif) agar suami dapat melaksanakan kewajiban sebelum mendapat haknya. Kewajiban suami adalah membayar nafkah, hak suami adalah diperkenankanya ia mentalak istri.

Kalau menganalisa terhadap tindakan suami yang tidak bisa membayar nafkahnya secara tunai, kemudian sudah jatuh tempo dan ia tetap tidak dapat melunasinya maka hakim akan melakukan pendekatan persuasif, yaitu pendekatan secara baik-baik dimana hakim menanyakan apa pekerjaannya dan berapa penghasilannya, kalau ternyata mantan suami masih belum sanggup membayar karena penghasilannya terbatas maka hakim akan menyuruh mantan suami untuk mengeluarkan dompetnya dihadapan sidang dan menanyakan berapa isi uang yang ada di dompetnya sekarang dan setelah itu hakim menyuruh mantan suami untuk mengeluarkan uangnya serta memberikannya kepada mantan istrinya.

Hal ini dilakukan tentunya atas persetujuan kedua belah pihak dan tidak ada paksaan dan biasanya istri sudah dapat menerima dengan penuh pengertian dan keikhlasan karena kebanyakan perceraian yang terjadi di Pengadilan Agama Marisa berlatar belakang ekonomi. Jika kedua belah pihak telah sepakat, maka sidang akan dilanjutkan seperti biasa, tapi kalau belum terjadi kesepakatan dan pihak kedua masih tetap meminta agar segera diberikan nafkah iddahnya maka hakim akan memberikan informasi tentang berbagai kemungkinan yang akan dihadapi oleh para pihak, serta mengemukakan saran dan solusi yang harus dilakukan agar kemungkinan buruk dapat dihindari, apa yang dilakukan oleh hakim tersebut tidak bertentangan dengan hukum. Sebab pada asasnya seorang Hakim harus membantu para pihak, sebagaimana disebutkan dalam pasal 5 ayat (2) Undang-Undang Nomor 14 Tahun 1970 jo pasal 58 ayat (2) Undang- Undang Nomor 7 Tahun 1989 yang berbunyi:

${ }^{21}$ Republik Indonesia, Undang-Undang Nomor 7 Tahun 1989 tentang Peradilan Agama, pasal 70 ayat (60), sebagaimana telah diubah untuk kedua kalinya Republik Indonesia, Undang-Undang Nomor 50 Tahun 2009 tentang Perubahan Kedua UndangUndang Nomor 7 Tahun 1989 tentang Peradilan Agama. 
Dalam perkara perdata Pengadilan membantu para pencari keadilan dan berusaha sekeras-kerasnya mengatasi segala rintangan dan hambatan untuk dapat tercapainya Peradilan yang sederhana, cepat dan biaya ringan. ${ }^{22}$

Hal ini disampaikan oleh Himawan Tatura Wijaya bahwa:

Langkah-langkah ini dianggap sudah efektif dan efisien oleh Pengadilan Agama Marisa sebab tidak pernah ada pihak yang merasa dirugikan dengan pendekatan persuasif ini, apalagi sampai ada pengajuan permohonan eksekusi. $^{23}$

Apabila ditinjau menurut perspektif gender, ketentuan pasal 70 ayat (3) Undang-Undang Nomor 7 Tahun 1989 tentang Peradilan Agama yang menyatakan:

Setelah penetapan tersebut memperoleh kekuatan hukum tetap, Pengadilan menentukan hari sidang penyaksian ikrar talak, dengan memanggil suami dan istri atau wakilnya untuk menghadiri sidang tersebut. $^{24}$

Ketentuan pasal ini menunjukkan bahwa pelaksanaan putusan permohonan izin ikrar talak yang telah berkekuatan hukum tetap tersebut menjadi kewajiban majelis hakim yang memutus perkara, bukan menjadi inisiatif dari pemohon (suami) yang mengajukan permohonan eksekusi putusan tersebut sebagaimana pelaksanaan putusan perkara-perkara yang bersifat contradictoir lainnya. Namun sebaliknya tidak terdapat ketentuan lainnya bagi majelis hakim tentang bagaimana pelaksanaan putusan akibat cerai talaknya tersebut. Karenanya sebagian para hakim berpendapat bahwa pelaksanaan/eksekusi akibat putusan cerai talak kembali menggunakan hukum acara perdata yang mengatur tentang eksekusi putusan.

${ }^{22}$ Republik Indonesia, Undang-Undang Nomor 14 Tahun 1970 tentang Kekuasaan Kehakiman. Lihat pula Republik Indonesia, Undang-Undang Nomor 7 Tahun 1989 tentang Peradilan Agama, pasal 58 ayat (2) sebagaimana telah diubah untuk kedua kalinya Republik Indonesia, Undang-Undang Nomor 50 Tahun 2009 tentang Perubahan Kedua UndangUndang Nomor 7 Tahun 1989 tentang Peradilan Agama.

${ }^{23}$ Himawan Tatura Wijaya, S.H.I., Wakil Ketua Pengadilan Agama Marisa, Wawancara, di Pengadila Agama Marisa, tanggal 16 April 2019.

${ }^{24}$ Republik Indonesia, Undang-Undang Nomor 7 Tahun 1989 tentang Peradilan Agama, pasal 70 ayat (3) sebagaimana telah diubah untuk kedua kalinya Republik Indonesia, Undang-Undang Nomor 50 Tahun 2009 tentang Perubahan Kedua UndangUndang Nomor 7 Tahun 1989 tentang Peradilan Agama. 
Efektifitas Pelaksanaan Peraturan Mahkamah Agung

Nomor 3 Tahun 2017 di Pengadilan Agama Marisa

Konsekuensinya pihak termohon (istri) harus mengajukan pelaksanaan putusan/eksekusi secara prosedural. Pihak istri harus mengajukan surat permohonan eksekusi putusan tersendiri kepada pengadilan Agama dengan membayar panjar biaya eksekusi dan lain sebagainya yang membutuhkan proses panjang dan biaya tidak sedikit. Sehingga terdapat kesan bahwa ketentuan tentang pelaksanaan atau eksekusi putusan cerai talak terjadi "bias-gender", karena peraturan tersebut hanya memberikan kemudahan kepada kaum lelaki saja, sehingga tidak memenuhi standar "keadilan gender" kepada termohon. Karena dengan ketentuan pasal 70 ayat (3) UndangUndang Nomor 7 Tahun 1989 tersebut Majelis Hakim dengan mudah memberikan hak suami (pemohon) untuk mengikrarkan talaknya. Namun sebaliknya tidak mencantumkan ketentuan yang mengatur sekaligus bagaimana pihak istri (termohon) dapat dengan mudah memperoleh haknya yang merupakan akibat hukum dari pengucapan ikrar talak oleh suami (Pemohon) tersebut yang wajib segera dilaksanakan pula.

Demikan pula SEMA Nomor 2015 yang melarang pencantuman amar putusan pembayaran nafkah istri sebelum ikrar talak jelas-jelas merugikan pihak perempuan, walaupun dalam penerapannya Majelis Hakim di Pengadilan Agama Marisa telah berupaya dengan melakukan pendekatan persuasif kepada pihak suami agar membayar penghukuman nafkah secara suka rela sebelum pelaksanaan ikrar talak, akan tetapi dapat dinilai bahwa pembuat regulasi belum sepenuhnya mendukung penegakkan gender.

\section{Upaya Hakim dalam Menjamin Eksekusi Nafkah Istri Pada Perkara Perceraian setelah Peraturan Mahkamah Agung Nomor 3 Tahun 2017 sebagai Upaya Penegakan Keadilan Gender}

\section{Cerai Talak}

Perkara cerai talak yang diputus selama Januari 2018 hingga Desember 2018 seluruhnya berjumlah 53 perkara. Berdasarkan hasi penelitian dan hasil analisis data putusan cerai talak tersebut, maka dapat dijabarkan sebagai berikut:

1. Perkara cerai talak yang diputus verstek sebanyak 41 perkara. Pada perkara ini Termohon atau suami tidak pernah hadir di persidangan, pada perkara ini tidak ada satupun putusan yang menghukum suami untuk membayar mut'ah dan nafkah iddah. 


\section{Lulu Sarini}

2. Pada cerai talak yang diputus kedua pihak hadir sebanyak 4 perkara. Pada perkara ini baik Pemohon (suami) dan Termohon (istri) keduanya hadir di persidangan sehingga dapat memberikan keterangan di persidangan, pada perkara ini 4 perkara putusan yang menghukum suami untuk membayar mut'ah dan nafkah iddah.

3. Pada cerai talak yang diputus kedua pihak hadir sebanyak 5 perkara. Pada perkara ini baik Pemohon (suami) dan Termohon (istri) keduanya hadir di persidangan sehingga dapat memberikan keterangan di persidangan, pada perkara ini 5 perkara suami tidak dihukum untuk membayar mut'ah dan nafkah iddah.

4. Perkara cerai talak yang dicabut sebanyak 4 perkara, yang digugurkan sebanyak 3 perkara, yang tidak diterima sebanyak 1 perkara. Pada perkara ini wajar jika suami tidak dihukum membayar mut'ah dan nafkah istri karena perkara ini diputus sebelum memeriksa pokok perkara.

Untuk lebih jelasnya penulis menjelaskan perbedaan amar putusan cerai talak sebelum dan sesudah PERMA Nomor 3 Tahun 2017 dalam tabel sebagai berikut:

\begin{tabular}{|c|l|l|}
\hline No & $\begin{array}{l}\text { Sebelum Adanya PERMA Nomor } \\
\text { 3 Tahun 2017 }\end{array}$ & $\begin{array}{l}\text { Sesudah Adanya PERMA Nomor } \\
\text { 3 Tahun 2017 }\end{array}$ \\
\hline 1 & $\begin{array}{l}\text { Tidak ada amar yang } \\
\text { memerintahkan kepada Pemohon } \\
\text { untuk melaksanakan putusan yakni } \\
\text { membayar beban sebelum ikrar } \\
\text { talakdiucapkan. }\end{array}$ & $\begin{array}{l}\text { Dalam pertimbangan hukum } \\
\text { hakim dan amar telah terdapat } \\
\text { adanya perintah pembayaran } \\
\text { nafkah iddah dan mut'ah yang } \\
\text { dibayarkan sebelum pengucapan } \\
\text { ikrar talakakan tetapi kurang } \\
\text { maksimal. }\end{array}$ \\
\hline 2 & $\begin{array}{l}\text { Bekas suami boleh membayar iddah } \\
\text { dan muta'ah sebelum atau sesudah } \\
\text { pengucapan ikrar talak }\end{array}$ & $\begin{array}{l}\text { Bekas suamidiperintahkan untuk } \\
\text { membayar iddah dan muta'ah } \\
\text { sebelum pengucapan ikrar talak }\end{array}$ \\
\hline
\end{tabular}

Pada putusan permohonan talak Nomor 65/Pdt.G/2014/PA.Msa sebelum diundangkannya PERMA Nomor 3 Tahun 2017 tentang Pedoman Mengadili Perempuan Berhadapan dengan Hukum, tidak ada amar memerintahkan kepada Pemohon untuk melaksanakan putusan yakni membayar beban sebelum ikrar talak diucapkan. Adapun amar pada putusan 
Efektifitas Pelaksanaan Peraturan Mahkamah Agung

Nomor 3 Tahun 2017 di Pengadilan Agama Marisa

permohonan cerai talak Nomor 65/Pdt.G/2014/PA.Msa sebelum adanya PERMA Nomor 3 Tahun 2017

\section{ME N G A D I L I}

\section{DALAM KONVENSI}

1. Mengabulkan permohonan Pemohon;

2. Memberi izin kepada Pemohon (Lk. A) untuk menjatuhkan talak satu raj'i terhadap Termohon (Pr. B) di depan sidang Pengadilan Agama Marisa pada waktu yang akan ditentukan kemudian;

\section{DALAM REKONVENSI}

1. Mengabulkan Gugatan Pemohon Rekonvensi sebagian;

2. Menetapkan Pemohon Rekonvensi sebagai pemegang hak hadlanah/pengasuhan terhadap kedua anak Pemohon Rekonvensi dan Termohon Rekonvensi yang masing-masing bernama $\mathbf{C}$ (laki-laki), umur 10 tahun dan $\mathbf{D}$ (perempuan), umur 1 tahun, 8 bulan;

3. Menghukum Tergugat Rekonvensi untuk membayar kepada Penggugat Rekonvensi nafkah kedua anak Penggugat Rekonvensi dan Tergugat yang masing-masing bernama $\mathbf{C}$ (laki-laki), umur 10 tahun dan $\mathbf{D}$ (perempuan), umur 1 tahun, 8 bulan keduanya minimal sebesar Rp 1.000.000,- (satu juta rupiah) perbulan selama kedua anak tersebut berada dalam hadlanah/asuhan Penggugat Rekonvensi;

4. Menghukum Tergugat Rekonvensi untuk membayar kepada Penggugat Rekonvensi berupa:

a. Mut'ah berupa uang sebesar Rp 2.000.000,- (dua juta rupiah);

b. Nafkah iddah selama 3 bulan masa iddah, seluruhnya sebesar Rp 3.000.000,- (tiga juta rupiah);

\section{DALAM KONVENSI DAN REKONVENSI}

Membebankan kepada Pemohon Konvensi/Termohon Rekonvensi untuk membayar biaya perkara sebesar Rp. 231.000,- (dua ratus tiga puluh satu ribu rupiah);

Analis penulis seharusnya Pemohon (suami) bisa atau boleh mengucapkan ikar talak sebelum membayar hak-hak istri atau nafkah istri tersebut. Akan tetapi Pengadilan dengan mengambil kebijakan demi melindungi hak-hak istri agar Pemohon membayar terlebih dahulu beban 


\section{Lulu Sarini}

yang diputuskan hakim sebelum mengucapakan ikrar, jikapun Pemohon belum bisa membayar, diberi keringanan oleh Majelis Hakim agar ditunda pengucapan ikrar talaknya sampai waktu yang ditentukan yakni 6 (enam) bulan. Tetapi jika sudah jatuh tempo 6 (enam) bulan Pemohon (suami) tidak bisa membayar juga maka gugurlah kekuatan penetapan tersebut dan perceraiaan batal serta tidak bisa diajukan lagi dengan alasan yang sama. Seperti di jelaskan pada Undang-Undang Nomor 7 Tahun 1989 tentang Peradilan Agama, pasal 70 angka (6) yaitu:

Jika suami dalam tenggang waktu 6 (enam) bulan sejak ditetapkan hari sidang penyaksian ikrar talak, tidak datang menghadap sendiri atau tidak mengirim wakilnya meskipun telah mendapat panggilan secara sah atau patut maka gugurlah kekuatan penetapan tersebut, dan perceraian tidak dapat diajukan lagi berdasarkan alasan yang sama. ${ }^{25}$

Kecuali istri merelakan suami tidak membayar, maka atas dasar kerelaaan istri tersebut, majelis dapat mengijinkan suami menjatuhkan talak.

Kemudian amar putusan cerai talak sesudah diundangkannya PERMA Nomor 3 Tahun 2017 sebagai berikut:

\section{ME N G A D I L I}

\section{DALAM KONVENSI}

1. Mengabulkan pemohonan Pemohon;

2. Memberi izin kepada Pemohon (Tn. E) untuk menjatuhkan talak satu raj'i terhadap Termohon (Pr. F) di depan persidangan Pengadilan Agama Marisa;

3. Menghukum Pemohon untuk memberikan kepada Termohon sesaat sebelum ikrar talak:

a. Mut'ah berupa uang sejumlah Rp.2.000.000.- (dua juta rupiah);

b. Iddah selama 3 bulan seluruhnya sejumlah Rp.3.000.000.- (tiga juta rupiah);

${ }^{25}$ Republik Indonesia, Undang-Undang Nomor 7 Tahun 1989 tentang Peradilan Agama, pasal 70 ayat (6) sebagaimana telah diubah untuk kedua kalinya Republik Indonesia, Undang-Undang Nomor 50 Tahun 2009 tentang Perubahan Kedua UndangUndang Nomor 7 Tahun 1989 tentang Peradilan Agama. 
Efektifitas Pelaksanaan Peraturan Mahkamah Agung

Nomor 3 Tahun 2017 di Pengadilan Agama Marisa

\section{DALAM REKONVENSI}

Menolak gugatan Penggugat Rekonvensi;

\section{DALAM KONVENSI DAN REKONVENSI}

Membebankan kepada Pemohon konvensi/Tergugat rekonvensi untuk membayar biaya perkara sejumlah Rp. 411.000.- (empat ratus sebelas ribu rupiah).

Analisis penulis bahwa pada putusan permohonan talak Nomor 108/Pdt.G/2018/PA.Msa setelah diundangkannya PERMA Nomor 3 Tahun 2017 tentang Pedoman Mengadili Perempuan Berhadapan dengan Hukum terdapat perubahan tetapi kurang maksimal, yakni di dalam pertimbangan hukum Hakim telah terdapat adanya perintah pembayaran hak istri berupa nafkah iddah dan mut'ah yang dibayarkan sebelum pengucapan ikrar talak, maka Hakim sudah memandang perlunya PERMA tersebut, yang harus ditegakkan dalam putusan. Sesuai dengan pasal 2 PERMA Nomor 3 Tahun 2017, yaitu:

Hakim mengadili perkara perempuan berhadapan dengan hukum berdasarkan asas:
a. Penghargaan atas harkat dan mertabatmanusia
b. Nondiskriminasi
c. Kesetaraangender
d. Persamaan di depan hukum
e. Keadilan
f. Kemanfaatan
g. Kepastian hukum ${ }^{26}$

Pada rumusan pleno Kamar Agama yang terdapat dalam SEMA Nomor 1 Tahun 2017, dalam rangka pelaksanaan PERMA Nomor 3 Tahun 2017 memberi perlindungan hukum bagi hak-hak perempuan pasca perceraian, maka pembayaran kewajiban akibat perceraian, khususnya nafkah iddah, mut'ah, dan nafkah madliyah, dapat dicantumkan pada amar putusan dengan kalimat dibayar sebelum pengucapan ikrar talak. Ikrar talak tidak dapat dilaksanakan bila istri keberatan atas suami tidak membayar

${ }^{26}$ Republik Indonesia, Peraturan Mahkamah Agung Nomor 3 Tahun 2017 tentang Perempuan Berhadapan dengan Hukum, pasal 2. 


\section{Lulu Sarini}

kewajiban tersebut pada saat itu, dan ketentuan ini mengubah huruf c angka 12, SEMA Nomor 3 Tahun 2015, in casu nafkah iddah, mut'ah dan nafkah madliyah.

Himawan Tatura Wijaya, S.H.I., selaku Wakil Ketua Pengadilan Agama Marisa menjelaskan:

Sebelum adanya PERMA Nomor 3 Tahun 2017 tentang pedoman mengadili perempuan berhadapan dengan hukum, dalam memutus perkara cerai talak tidak ada ketentuan untuk mencantumkan amar dan atau menambah amar yang memerintahkan kepada Pemohon atau suami untuk membayar nafkah iddah dan mut'ah kepada istrinya sebelum pengucapan ikrar talak di dalam putusannya, sesuai dengan SEMA Nomor 1 Tahun $2017 .^{27}$

Berdasarkan penelitian putusan Nomor 108/Pdt.G/2018/PA.Msa amar menghukum suami membayar nafkah iddah dan mut'ah dan seterusnya ditambah kalimat yang memerintahkan Pemohon untuk membayar sebelum pengucapan ikrar talak, sebagaimana yang diperintahkan SEMA Nomor 1 Tahun 2017, sehingga suami tidak bisa mengikrarkan kecuali atas izin istrinya.

\section{Cerai Gugat}

Perkara cerai gugat yang diputus selama bulan Januari 2018 hingga bulan April 2019 seluruhnya berjumlah 53 perkara. Berdasarkan penelitian penulis terhadap putusan cerai gugat sebelum diundangkannya PERMA Nomor 3 Tahun 2018 tentang pedoman mengadili perempuan berhadapan dengan hukum sebagai contoh Putusan Nomor 10/Pdt.G/2016/PA.Msa dengan amar sebagai berikut:

\section{ME N G A D I L I}

1. Mengabulkan gugatan Penggugat;

2. Menjatuhkan talak satu bain shughra Tergugat (Tn. G) terhadap Penggugat (Ny. H);

${ }^{27}$ Himawan Tatura Wijaya, S.H.I., Wakil Ketua Pengadilan Agama Marisa, Wawancara, di Pengadila Agama Marisa, tanggal 16 April 2019. 
Efektifitas Pelaksanaan Peraturan Mahkamah Agung

Nomor 3 Tahun 2017 di Pengadilan Agama Marisa

3. Memerintahkan Panitera Pengadilan Agama Marisa untuk mengirimkan salinan putusan ini setelah berkekuatan hukum tetap kepada Pegawai Pencatat Nikah Kantor Urusan Agama Kecamatan Suwawa, Kabupaten Bone Bolango, Pegawai Pencatat Nikah Kantor Urusan Kecamatan Randangan, Kabupaten Pohuwato dan Pegawai Pencatat Nikah Kantor Urusan Kecamatan Paguat, Kabupaten Pohuwato untuk dicatat dalam daftar yang disediakan untuk itu;

4. Membebankan kepada Penggugat untuk membayar biaya perkara sejumlah Rp. 421.000,- (empat ratus dua puluh satu ribu rupiah);

Sedangkan putusan cerai gugat sesudah diundangkannya PERMA Nomor 1 Tahun 2017 tentang pedoman mengadili perempuan berhadapan dengan hukum, sebagai contoh Putusan Nomor 48/Pdt.G/2018/PA.Msa dengan amar putusan sebagai berikut:

\section{E N G A D I L I}

1. Mengabulkan gugatan Penggugat;

2. Menjatuhkan talak satu ba'in sughra Tergugat (Tn. I) terhadap Penggugat (Ny. J);

3. Memerintahkan Panitera Pengadilan Agama Marisa untuk mengirimkan salinan putusan yang telah berkekuatan hukum tetap kepada Pegawai Pencatat Nikah Kantor Urusan Agama Kecamatan Paguat, Kabupaten Pohuwato untuk dicatat dalam daftar yang disediakan untuk itu;

4. Membebankan kepada Penggugat untuk membayar biaya perkara yang hingga kini sejumlah Rp 261.000,00 (dua ratus enam puluh satu ribu).

Untuk memudahkan penulis akan menuangkan dalam tabel sebagai berikut:

\begin{tabular}{|c|l|l|}
\hline No & $\begin{array}{l}\text { Sebelum Adanya PERMA Nomor } \\
\text { 3 Tahun 2017 }\end{array}$ & $\begin{array}{l}\text { Sesudah Adanya PERMA Nomor } \\
\text { 3 Tahun 2017 }\end{array}$ \\
\hline 1 & $\begin{array}{l}\text { Bekas istri tidak mendapatkan } \\
\text { mut'ah, iddah dan nafkah } \\
\text { madliyah. }\end{array}$ & $\begin{array}{l}\text { Bekas istri tidak mendapatkan } \\
\text { mut'ah, iddah dan nafkah } \\
\text { madliyah. }\end{array}$ \\
\hline
\end{tabular}

Dari data putusan perkara cerai gugat yang diputuskan sejak bulan Januari 2018 sampai dengan Desember 2018 maka ditemukan fakta sebagai berikut: 


\section{Lulu Sarini}

1. Perkara cerai gugat yang diputus verstek sebanyak 122 perkara. Pada perkara ini Tergugat atau suami tidak pernah hadir di persidangan, pada perkara ini tidak ada satupun putusan yang menghukum suami untuk membayar mut'ah dan nafkah iddah.

2. Pada cerai gugat yang diputus kedua pihak hadir sebanyak 6 perkara. Pada perkara ini baik Penggugat (istri) dan Tergugat (suami) keduanya hadir di persidangan sehingga dapat memberikan keterangan di persidangan, pada perkara ini tidak ada satupun putusan yang menghukum suami untuk membayar mut'ah dan nafkah iddah,

3. Perkara cerai gugat yang dicabut sebanyak 7 perkara, Perkara cerai gugat yang digugurkan sebanyak 1 perkara. Pada perkara ini suami tidak dihukum membayar mut'ah dan nafkah istri karena perkara ini diputus sebelum memeriksa pokok perkara.

Berdasarkan Himawan Tatura Wijaya, S.H.I. selaku Wakil Ketua Pengadilan Agama Marisa menjelaskan bahwa:

Alasan Hakim tidak memberikan hak-hak istri berupa nafkah iddah dan mut'ah pada putusan gugatan cerai yang diajukan oleh pihak istri adalah karena dengan mengajukan gugatan perceraian itu, istri dianggap nusyuz sehingga penggugat tidak berhak mendapat nafkah iddah. Selain nusyuz, talak akibat cerai gugat termasuk talak ba'in karena dijatuhkan oleh Pengadilan. Talak ba'in yaitu talak yang tidak bisa rujuk kembali, jika ingin kembali maka harus menikah kembali. ${ }^{28}$

Pendapat penulis menyebutkan bahwa PERMA Nomor 3 Tahun 2017 belum efektif diterapkan pada gugatan perceraian karena termasuk talak ba'in yang dimana suami tidak berkewajiban memberikan nafkah iddah kepada istri yang sudah tidak menjadi tanggungan suami lagi, dan juga tidak memberikan nafkah mut'ah karena yang meminta cerai adalah istri yang di mana mut'ah harus diartikan sebagai penggembira atau hadiah darisuami.

Perkawinan yang dalam istilah agama disebut "nikah" ialah melakukan suatu akad atau perjajian untuk mengikatkan diri antara seorang laki-laki dan perempuan untuk menghalalkan hubungan kelamin antara kedua belah pihak, dengan dasar sukarela dan keridhaan kedua belah pihak untuk mewujudkan suatu kebahagiaan hidup berkeluarga yang diliputi kasih sayang dan ketentraman dengan cara-cara yang diridhoi oleh Allah swt.

${ }^{28}$ Himawan Tatura Wijaya, S.H.I., Wakil Ketua Pengadilan Agama Marisa, Wawancara, di Pengadila Agama Marisa, tanggal 16 April 2019. 
Efektifitas Pelaksanaan Peraturan Mahkamah Agung

Nomor 3 Tahun 2017 di Pengadilan Agama Marisa

Untuk mengatur lebih lanjut hal-hal yang diperlukan bagi kelancaran penyelenggaraan peradilan, Mahkamah Agung telah menerbitkan PERMA Nomor 3 Tahun 2017 tentang Pedoman Mengadili Perkara Perempuan Berhadapan dengan Hukum. PERMA tersebut pada intinya bertujuan untuk memastikan penghapusan segala potensi diskriminasi terhadap perempuan yang berhadapan dengan hukum dan juga agar Hakim memiliki acuan dalam memahami dan menerapkan kesetaraan gender dan prinsip-prinsip Nondiskriminasi dalam mengadili suatu perkara. PERMA ini merupakan suatu langkah maju bagi dunia peradilan di Indonesia, dan diharapkan menjadi standar bagi Hakim dan segenap aparatur Pengadilan dalam menangani perkara yang melibatkan perempuan.

Dalam pelaksanaan PERMA tentunya Majelis Hakim yang memutus perkara mendapatkan beberapa kendala. Berdasarkan wawancara yang dengan Himawan Tatura Wijaya, S.H.I., selaku Wakil Ketua Pengadilan Agama Marisa yakni beliau menyatakan bahwa

Jika perkara permohonan yakni yang mengajukan adalah suami, pihak istri tidak pernah hadir (verstek) dalam persidangan sedangkan sudah dipanggil oleh pihak pengadilan maka pihak istri tidak mendapatkan nafkah iddah dan mut'ah dan istri dinilai nusyuz. Kedua, yang melatar belakangi perceraian di Kabupaten Marisa rata-rata dari keluarga miskin atau menengah kebawah, hal ini akan menjadi kendala tersendiri untuk Hakim dalam menjatuhkan atau membebani pihak suami untuk membayar nafkah iddah dan mut'ah, sedangkan rumah tangga mereka sudah tidak mungkin bersatu kembali. Ketiga, gugatan perceraian termasuk dalam talak ba'in, artinya talak yang dijatuhkan oleh pengadilan dan talak ba'in tersebut tidak bisa rujuk kembali, jika ingin kembali maka harus dengan nikah baru, hal tersebut yang melatar belakangi istri tidak mendapatkan haknya yang berupa nafkah iddah. Karena istri sudah bukan tanggung jawab suamilagi. ${ }^{29}$

Menurut PERMA Nomor 3 Tahun 2017 tentang Pedoman Mengadili Perempuan Berhadapan dengan Hukum meskipun putusan verstek, hak-hak perempuan harus tetap terpenuhi. Selama ini sebelum adanya PERMA tersebut hak-hak perempuan tidak terpenuhi sehingga menjadi kurang adil bagi perempuan.Dengan alasan keadilan maka putusan verstek seharusnya

${ }^{29}$ Himawan Tatura Wijaya, S.H.I., Wakil Ketua Pengadilan Agama Marisa, Wawancara, di Pengadila Agama Marisa, tanggal 16 April 2019. 


\section{Lulu Sarini}

istri tetap mendapat hak-haknya (nafkah mut'ah).Akan tetapi hal ini dianggap bertentangan dengan fiqh. Putusan verstek permohonan talak biasanya tidak mendapat mut'ah dan nafkah iddah disebabkan karena istri tidak datang di Pengadilan ketika dipanggil dengan patut maka hak-haknya gugur.Namun dengan adanya PERMA Nomor 3 Tahun 2017 tentang pedoman mengadili perempuan berhadapan dengan hukum, walaupun istri tidak datang dalam persidangan hakim haruslah tetap memberikan hak-hak istri seperti (nafkah mut'ah) secara ex-officio demi menciptakan keadilan di kedua pihak mengingat suami isri tersebut sudah saling mencintai dan hidup bersama membangun rumah tangga dan istri mengabdi kepada suaminya.

Suami yang pada waktu hari ikrar talak belum siap membayar maka pemohon diberi dan atau meminta waktu selama 6 (enam) bulan.Pandangan Hakim dalam waktu 6 (enam) bulan tersebut dirasa pihak pemohon mampu tetap memberikan nafkah terhadap termohon, bahkan diharap mampu memperbaiki hubungan antara pemohon dan termohon agar bisa rukun kembali.Jika dalam waktu tersebut pemohon tidak membayar dan tidak datang lagi ke Pengadilan Agama maka putusan tidak mempunyai kekuatanhukum.

Namun setelah adanya SEMA Nomor 1 Tahun 2017 dirubah menjadi yang membolehkan menambah amar supaya pemohon membayar beban sebelum atau saat pemohon mengucap ikrar talak yang isinya kalimat dibayar sebelum pengucapan ikrar talak, dan jika istri bersedia atau tidak keberatan suami tidak membayar kewajibannya kepada istri, maka ikrar talak dapat dilaksanakan.

Tujuan dicantumkannya atau ditambahkannya didalam amar putusan dengan kalimat nafkah iddah, mut'ah dan madliyah dibayar sebelum pengucapan ikrar talak adalah agar pemohon melaksanakan perintah majelis hakim dan agar ada kekuatan hukum yang mengikat antara pemohon dan termohon.Selain itu untuk melindungi perempuan (istri) dan mempermudah mendapatkan hak-haknya tanpa permohonan eksekusi.

Pada permohonan cerai yang dijatuhkan oleh pihak suami, harus membayar nafkah-nafkah yang menjadi hak-hak istri seperti nafkah iddah dan mut'ah.Suami harus membayar lunas sebelum mengucap ikrar talak. Jika hal seperti itu sudah terlaksana artinya sudah tidak menjadi masalah, terkecuali pihak suami (pemohon) belum membawa atau belum memiliki uang untuk membayar hak-hak istri. Dalam hal itu Hakim menunda pengucapan ikrar talak selama 6 (enam) bulan seperti yang sudah di sebutkan 
Efektifitas Pelaksanaan Peraturan Mahkamah Agung

Nomor 3 Tahun 2017 di Pengadilan Agama Marisa

Pasal 70 angka 6 Undang-Undang Nomor 7 Tahun 1989 guna melindungi hak-hak istri.

Berdasarkan ketentuan tersebut di atas terdapat kendala dalam pelaksanaan jika yang bercerai adalah dari keluarga ekonomi menengah ke bawah karena setelah diberikan waktu selama 6 (enam) bulan pihak suami yang akan mengucapkan talak tidak kembali lagi ke Pengadilan dengan alasan tidak bisa memenuhi pembayaran tersebut, hal ini akan menimbulkan mudharat yang sangat bersar terhadap pasangan itu karena suami istri tersebut tidak akan rukun kembali. Pada akhirnya biasanya pihak istri bersedia tidak dibayarkannya iddah ataupun mut'ah demi bisa berpisah atau bercerai dengan suaminya, dan Hakim memenuhi permintaan tersebut dengan melangsungkan perceraianmereka.

Berdasarkan wawancara Himawan Tatura Wijaya, S.H.I mengatakan bahwa:

Kendala dalam melaksanakan PERMA Nomor 3 Tahun 2017 tentang pedoman mengadili perempuan berhadapan dengan hukum pada cerai gugat. Bahwa istri yang meminta cerai adalah istri yang nusyuz.Karena cerai gugat yang mengajukan adalah istri, sehingga istri dianggap nusyuz.Tetapi jika tidak nusyuz berdasarkan perma harusnya ditetapkan pemberian nafkah iddah dan mut'ah.Sehingga hal ini menjadi penghambat dalam penerapannya, selain itu juga menjadi tidak maksimal karena Majelis Hakim dalam memutus perkara lebih condong menggunakan fiqh. Selain itu yang menjadi faktor penghalang berjalannya PERMA Nomor 3 Tahun 2017 tentang pedoman mengadili perempuan berhadapan dengan hukum adalah pihak suami dalam perkara cerai gugat tidak hadir di persidangan serta pihak istri tidak memandang penting nafkah iddah dan mut'ah yang penting dapat bercerai dengan suami. ${ }^{30}$

Dalam perkara cerai gugat yang diajukan istri di Pengadilan Agama, Hakim menggunakan kaidah fiqh yang telah dijadikan peraturan perundangundangan untuk memutus perkara tersebut. Selama ini paradigma Hakim apabila istri mengajukan cerai kepada suami maka dianggap nusyuz atau membangkang sesuai dengan kaidah fiqh, sehingga istri tidak mendapat hakhaknya seperti nafkah iddah dan nafkah lampau, hal ini sesuai dengan kaidah

${ }^{30}$ Himawan Tatura Wijaya, S.H.I., Wakil Ketua Pengadilan Agama Marisa, Wawancara, di Pengadila Agama Marisa, tanggal 16 April 2019. 


\section{Lulu Sarini}

fiqh yang telah dijadikan Undang-Undang dan Kompilasi Hukum Islam. Kemudian muncul PERMA Nomor 3 Tahun 2017 tentang Pedoman Mengadili Perempuan Berhadapan dengan Hukum, sesuai dengan PERMA tersebut, Mahkamah Agung mengharapkan supaya Hakim dalam memutus perkara perceraian dapat melihat alasan-alasan istri yang mengajukan gugatan perceraian tersebut. Istri dapat dianggap nusyuz atau tidak, adalah setelah adanya pembuktian, jika istri tidak terbukti nusyuz maka istri tetap mendapatkan hak-haknya seperti nafkah iddah dan lampau sesuai dengan maksud Pasal 2 PERMA Nomor 3 Tahun 2017 tentang pedoman mengadili perempuan berhadapan dengan hukum. Sedangkan jika istri terbukti nusyuz maka istri tidak mendapatkan hak-haknya seperti nafkah iddah dan nafkah lampau. Dengan adanya PERMA tersebut diharapkan dapat merubah paradigma sebagian Hakim yang selama ini menganggap istri yang mengajukan gugatan cerai adalah nusyuz, menjadi tidak dianggap nusyuz sebelum ada pembuktian tentang kenusyuzannya.

\section{Kesimpulan}

Kesimpulan yang dapat dari hasil analisa tersebut, antara lain:

1. PERMA Nomor 3 Tahun 2017 tentang Pedoman Mengadili Perempuan Berhadapan dengan Hukum sudah efektif menegakkan keadilan gender di Pengadilan Agama Marisa, pada perkara cerai talak tertentu yaitu yang istrinya hadir dan mengajukan tunt utan rekonvensi tentang nafkah di persidangan. Adapun pada perkara verstek maupun perkara yang istrinya tidak mengajukan tuntutan nafkah maka PERMA Nomor 3 Tahun 2017 ini tidak efektif atau tidak diterapkan.

2. PERMA Nomor 3 Tahun 2017 tentang Pedoman Mengadili Perempuan Berhadapan dengan Hukum tidak efektif sama sekali dalam menegakkan keadilan gender pada perkara cerai gugat di Pengadilan Agama Marisa, karena dianggap bertentangan dengan fikih.

3. Berdasarkan hasil penelitian dan pembahasan dapat disimpulkan perbedaan putusan Hakim sebelum dan sesudah adanya PERMA Nomor 3 Tahun 2017 tentang pedoman mengadili perempuan berhadapan dengan hukum pada:

a. Putusan permohonan cerai talak sebelum dan sesudah adanya PERMA Nomor 3 Tahun 2017 tentang pedoman mengadili perempuan berhadapan dengan hukum, pada putusan permohonan 
Efektifitas Pelaksanaan Peraturan Mahkamah Agung

Nomor 3 Tahun 2017 di Pengadilan Agama Marisa

talak Nomor 65/Pdt.G/2014/PA.Msa sebelum diundangkannya SEMA Nomor 1 Tahun 2017, tidak ada amar memerintahkan kepada Pemohon untuk melaksanakan putusan yakni membayar beban sebelum ikrar talak diucapkan. Sedangkan putusan permohonan talak Nomor 108/Pdt.G/2018/PA.Msa setelah di undangkannya SEMA Nomor 1 Tahun 2017 terdapat perubahan tetapi kurang maksimal. Karena di dalam pertimbangan hukum. Hakim sudah menerapkan SEMA Nomor 1 Tahun 2017 telah terdapat adanya perintah pembayaran hak istri berupa nafkah iddah dan mut'ah yang dibayarkan sebelum pengucapan ikrar talak, namun dalam amar tersebut masih digabung dengan amar pembebananan nafkah iddah dan mut'ah sehingga amar putusan kurang jelas dalam mendapatkan kepastian hukum.

b. Putusan gugatan perceraian sebelum dan sesudah adanya SEMA Nomor 3 Tahun 2018, pada putusan gugatan perceraian Nomor 10/Pdt.G/2016/PA.Msa sebelum diundangkannya SEMA Nomor 3 Tahun 2018, istri tidak mendapatkan hak-haknya atau nafkah iddah dan mut'ah. Sedangkan Pada putusan gugatan perceraian Nomor 48/Pdt.G/2018/PA.Msa sesudah diundangkannya SEMA Nomor 3 Tahun 2018, istri juga tidak mendapatkan hak-haknya atau nafkah iddah dan mut'ah, sehingga dalam putusan gugatan perceraian sebelum dan sesudah adanya SEMA Nomor 3 Tahun 2018.

4. Kendala yang timbul dalam pelaksanaan SEMA Nomor 3 Tahun 2018 dalam memutus perkara perceraian di Pengadilan Agama Marisa, yaitu:

a. Jika dalam permohonan cerai talak persidangan dilakukan secara verstek maka istri dinilai nusyuz sehingga tidak mendapatkan nafkah iddah dan mut'ah.

b. Apabila para pihak merupakan keluarga kurang mampu, Hakim kesulitan untuk menjatuhkan atau membebani pihak suami untuk membayar nafkah iddah dan mut'ah.

c. Gugatan perceraian termasuk dalam talak ba'in, sehingga suami tidak bertanggung jawab atas massa iddah bekas istrinya karena untuk rujuk kembali harus melalui menikah baru.

d. Hakim Pengadilan Agama memutus perkara perceraian menggunakan kaidah fiqh yang telah dijadikan Undang-Undang dan Kompilasi Hukum Islam, sehingga paradigma sebagian Hakim menganggap istri nusyuz serta tidak mendapatkan hak-haknya. 


\section{Daftar Pustaka}

Fakih, Mansour. Analisis Gender dan Transformasi Sosial, (Cet. VII; Yogyakarta: Pustaka Pelajar, 2003), 232.

Fidaweri. Hukum Islam Tentang Fasakh Perkawinan. Jakarta: Pedoman Ilmu Jaya, 1989.

Hakim, Rahmat. Hukum Perkawinan Islam. Bandung: CV Pustaka Setia, 2000.

Hamid, Zahri. Pokok-Pokok Hukum Perkawinan Islam dan Undang-Undang Perkawinan di Indonesia. Cet I; Yogyakarta: Bina Cipta, 1987

Latif, Djamil. Aneka Hukum Perceraian di Indonesia. Cet. I; Jakarta: Ghalia Indonesia, 1982.

Rasyidi, Lili. Hukum Perkawinan dan Perceraian di Malaysia dan Indonesia. Cet. X: Bandung: Penerbit Alumni, 1982.

Republik Indonesia, Peraturan Mahkamah Agung Nomor 3 Tahun 2017 tentang Perempuan Berhadapan dengan Hukum.

Republik Indonesia, Undang-Undang Nomor 14 Tahun 1970 tentang Kekuasaan Kehakiman.

Republik Indonesia, Undang-Undang Nomor 7 Tahun 1989 tentang Peradilan Agama, pasal 70 ayat (60), sebagaimana telah diubah untuk kedua kalinya Republik Indonesia, Undang-Undang Nomor 50 Tahun 2009 tentang Perubahan Kedua Undang-Undang Nomor 7 Tahun 1989 tentang Peradilan Agama.

Republik Indonesia. Het Herziene Indonesisch Reglement.

Republik Indonesia. Peraturan Mahkamah Agung Nomor 3 Tahun 2017 tentang Perempuan Berhadapan dengan Hukum.

Summa, Muhammad Amin. Hukum Keluarga Islam di dunia Islam. Jakarta: Raja Grafindo Persada, 2005), 152.

www.badilag.net, "Info sekitar Badilag tertanggal 22-9-2018” 